\title{
Recommendations for the Management of Hepatitis C Virus Infection Among People Who Inject Drugs
}

\author{
Geert Robaeys, ${ }^{1,2,3, a}$ Jason Grebely, ${ }^{4, a}$ Stefan Mauss, ${ }^{5}$ Philip Bruggmann, ${ }^{6}$ Joseph Moussalli, ${ }^{7,8}$ Andrea De Gottardi, ${ }^{9}$ \\ Tracy Swan, ${ }^{10}$ Amber Arain, ${ }^{1,3}$ Achim Kautz, ${ }^{11}$ Heino Stöver, ${ }^{12}$ Heiner Wedemeyer, ${ }^{13}$ Martin Schaefer, ${ }^{14,15}$ Lynn Taylor, $^{16}$ \\ Markus Backmund, ${ }^{17,18}$ Olav Dalgard, ${ }^{19}$ Maria Prins, ${ }^{20,21}$ and Gregory J. Dore, ${ }^{4,22}$ on behalf of the International Network \\ on Hepatitis in Substance Users \\ ${ }^{1}$ Department of Gastroenterology and Hepatology, Ziekenhuis Oost Limburg, Genk, ${ }^{2}$ Department of Hepatology UZ Leuven, and ${ }^{3}$ Faculty of Medicine and \\ Life Sciences, Limburg Clinical Research Program, Hasselt University, Belgium; ${ }^{4}$ Kirby Institute, University of New South Wales, Sydney, Australia; \\ ${ }^{5}$ Center for HIV and Hepatogastroenterology, Düsseldorf, Germany; ${ }^{6}$ Arud Centres of Addiction Medicine, Zurich, Switzerland; ${ }^{7}$ Hôpital Pitié-Salpêtrière, \\ and ${ }^{8}$ Université Pierre et Marie Curie, Paris VI, Paris, France; ${ }^{9}$ Hepatology, Clinic of Visceral Surgery and Medicine, Inselspital, Berne, Switzerland; \\ ${ }^{10}$ Treatment Action Group, New York, New York; ${ }^{11}$ European Liver Patients Association, Cologne, ${ }^{12}$ Institute of Addiction Research, University of Applied \\ Sciences, Frankfurt am Main, ${ }^{13}$ Department of Gastroenterology, Hepatology and Endocrinology, University of Hannover; ${ }^{14}$ Department of Psychiatry, \\ Psychotherapy and Addiction Medicine, Kliniken Essen-Mitte, Essen, and ${ }^{15}$ Department of Psychiatry and Psychotherapy-CCM, Charité- \\ Universitätsmedizin Berlin, Germany; ${ }^{16}$ Department of Medicine, Brown University, Providence, Rhode Island; ${ }^{17}$ Ludwig-Maximilians-University, and \\ ${ }^{18}$ Praxiszentrum im Tal Munich, Munich, Germany; ${ }^{19}$ Department of Infectious Diseases, Akershus University Hospital, Lørenskog, Norway; ${ }^{20}$ Department \\ of Research, Cluster Infectious Diseases, Public Health Service of Amsterdam, and ${ }^{21}$ Department of Internal Medicine, Center for Infection and Immunity \\ Amsterdam, Academic Medical Centre, Amsterdam, the Netherlands; and ${ }^{22} \mathrm{HIV} /$ Immunology/Infectious Diseases Clinical Services Unit, St Vincent's \\ Hospital, Sydney, Australia
}

In the developed world, the majority of new and existing hepatitis $\mathrm{C}$ virus (HCV) infections occur among people who inject drugs (PWID). The burden of HCV-related liver disease in this group is increasing, but treatment uptake among PWID remains low. Among PWID, there are a number of barriers to care that should be considered and systematically addressed, but these barriers should not exclude PWID from HCV treatment. Furthermore, it has been clearly demonstrated that HCV treatment is safe and effective across a broad range of multidisciplinary healthcare settings. Given the burden of HCV-related disease among PWID, strategies to enhance HCV assessment and treatment in this group are urgently needed. These recommendations demonstrate that treatment among PWID is feasible and provides a framework for HCV assessment, management, and treatment. Further research is needed to evaluate strategies to enhance assessment, adherence, and SVR among PWID, particularly as new treatments for HCV infection become available.

Keywords. drug users; injecting; injection; guidelines; HCV; HIV.

In the developed world, $50 \%-80 \%$ of hepatitis $\mathrm{C}$ virus (HCV) infection is among people who inject drugs (PWID) [1]. Hereafter, "PWID" will refer to people with current or "active" injection drug use (IDU),

${ }^{\mathrm{a}} \mathrm{G}$. R. and J. G. contributed equally to this work

Correspondence: Geert Robaeys, MD, PhD, Professor of Medicine and Life Sciences, Department of Gastroenterology and Hepatology, Ziekenhuis Oost Limburg, Schiepse Bos 6, B 3600 Genk, Belgium (geert.robaeys@zol.be).

Clinical Infectious Diseases 2013:57(S2):S129-37

(C) The Author 2013. Published by Oxford University Press on behalf of the Infectious Diseases Society of America. All rights reserved. For Permissions, please e-mail: journals.permissions@oup.com.

DOI: $10.1093 /$ cid/cit302 which is generally defined as use in the past 6 months, and to former injectors who are still active noninjection drug users and/or on opioid substitution therapy (OST). The natural history of HCV (increase in liver cirrhosis after 15-20 years), and an aging cohort of PWID, means that a large burden of advanced liver disease is anticipated in the next decade [2].

Until recently, $\mathrm{HCV}$ treatment guidelines excluded PWID, due to concerns about poor adherence, adverse events, and reinfection [3]. Successful HCV treatment studies among PWID challenged this paradigm [4-35], and guidelines have been revised to consider HCV treatment among PWID on a "case-by-case" basis [36-38]. 
Despite revised guidelines, few PWID have received HCV treatment [39-42]. Enhanced HCV assessment and treatment in PWID will be required to reduce future HCV-related morbidity and mortality [43]. The availability of effective, tolerable, and simpler direct-acting antivirals (DAAs) should improve the feasibility of this approach. The International Network of Hepatitis in Substance Users established an expert panel to develop recommendations to enhance $\mathrm{HCV}$ assessment, management, and treatment among PWID.

\section{METHODS}

The recommendations have been graded according to the Grading of Recommendations Assessment, Development, and Evaluation (GRADE) system, [38]. The strength of recommendations reflects the quality of underlying evidence (Table 1 ). The quality of the evidence has been classified in 1 of 3 levels: high (A), moderate $(\mathrm{B})$, or low $(\mathrm{C})$. The GRADE system offers 2 grades of recommendation: strong (1) or weak (2).

\section{Epidemiology and Prevention of HCV}

Prevalence of HCV among PWID is 65\% [44] and $>80 \%$ among long-term PWID [45]. HCV genotypes $1 \mathrm{a}, 1 \mathrm{~b}$, and $3 \mathrm{a}$ are common among PWID [46]. Genotype $4 \mathrm{~d}$ is common among PWID in Europe [47], and 6 in Southeast Asia [48]. Incidence of HCV in PWID is $2 \%-45 \%$ per annum [45]. High coverage of combined harm reduction programs (opioid substitution treatment [OST] and needle exchange programs) can reduce $\mathrm{HCV}$ incidence [49-51]. Modeling studies suggest that HCV treatment for PWID could reduce transmission [52].

\section{Recommendations}

1. PWID should be routinely and voluntarily tested for HCV antibodies/RNA and if negative, every 6-12 months (B1).

2. PWID should be provided with clean drug injecting equipment and access to OST as part of widespread comprehensive harm reduction programs, including in prisons (B1).

\section{Natural History of HCV and Effects of Drugs on the Liver}

Chronic HCV infection develops in 75\% [53], with 10\%-20\% developing cirrhosis over 20-30 years of infection [2]. In a meta-analysis of HCV-infected PWID, the 20-year cirrhosis prevalence was $15 \%$ [54]. Despite slow HCV disease progression over the initial 20 years of infection, factors contributing to fibrosis progression include age, continued moderate to heavy alcohol use, human immunodeficiency virus (HIV) infection, obesity, and insulin resistance (reviewed in [2]).

Despite misconceptions among affected populations and healthcare workers, no liver toxicity is reported for heroin [55] or methadone [56]. Buprenorphine occasionally increases transaminases [57]. Methylenedioxymethamphetamine rarely
Table 1. Evidence Grading (Adapted From the GRADE System)

\begin{tabular}{|c|c|c|}
\hline Evidence & Notes & $\begin{array}{c}\text { Quality of } \\
\text { Evidence/ } \\
\text { Grade }\end{array}$ \\
\hline High quality & $\begin{array}{l}\text { Further research is very } \\
\text { unlikely to change our } \\
\text { confidence in the estimate } \\
\text { of effect. }\end{array}$ & A \\
\hline $\begin{array}{c}\text { Moderate } \\
\text { quality }\end{array}$ & $\begin{array}{l}\text { Further research is likely to } \\
\text { have an important impact on } \\
\text { our confidence in the } \\
\text { estimate of effect and may } \\
\text { change the estimate. }\end{array}$ & $\mathrm{B}$ \\
\hline Low quality & $\begin{array}{l}\text { Further research is very likely } \\
\text { to have an important impact } \\
\text { on our confidence in the } \\
\text { estimate of effect and is } \\
\text { likely to change the } \\
\text { estimate. Any change of } \\
\text { estimate is uncertain. }\end{array}$ & C \\
\hline \multicolumn{3}{|c|}{ Recommendation Notes } \\
\hline Strong & $\begin{array}{l}\text { Factors influencing the } \\
\text { strength of the } \\
\text { recommendation included } \\
\text { the quality of the evidence, } \\
\text { presumed patient-important } \\
\text { outcomes, and cost. }\end{array}$ & 1 \\
\hline Weak & $\begin{array}{l}\text { Variability in preferences and } \\
\text { values, or more uncertainty. } \\
\text { Recommendation is made } \\
\text { with less certainty, higher } \\
\text { cost, or resource } \\
\text { consumption. }\end{array}$ & 2 \\
\hline
\end{tabular}

causes acute liver failure due to direct liver toxicity [58, 59], and little is known about methamphetamine-related liver toxicity [60]. Heavy alcohol consumption is associated with a higher risk of cirrhosis [61]. Tobacco [62] and daily cannabis [63, 64] smoking may increase fibrosis progression, but further studies are needed. Coffee consumption is associated with lower necroinflammatory activity and less-advanced fibrosis $[65,66]$.

Aging cohorts of PWID with chronic HCV and low treatment uptake are currently leading to an increasing burden of $\mathrm{HCV}$-related morbidity and mortality [2]. In several countries where PWID are the major population affected by HCV, 20\%$25 \%$ of deaths among $\mathrm{HCV}$-infected individuals are from liver disease and 15\%-30\% are from drug-related causes [2].

\section{Recommendations}

1. PWID should be counseled to moderate alcohol intake, or abstain if there is evidence of advanced liver disease (A1).

2. PWID should be counseled to moderate cannabis use, or abstain if there is evidence of advanced liver disease (B2).

3. Cessation of injecting is not required to limit $\mathrm{HCV}$ disease progression (B2).

4. The potential impact of drug use on the liver should be discussed with PWID (C2). 


\section{Noninvasive Liver Fibrosis Assessment}

Liver biopsy is the gold standard for liver fibrosis assessment, but it is invasive and logistically difficult. As per international guidelines [37, 38], noninvasive methods such as transient elastography or well-established panels of biomarkers of fibrosis are acceptable for liver disease assessment. Noninvasive methods have excellent utility for the identification of HCV-related cirrhosis, but lesser accuracy for earlier stages [67], and can predict HCV-related survival [68]. Combining multiple modalities achieves the best performance [69]. Noninvasive tests are cost-effective [70]. Among PWID, transient elastography can enhance liver disease screening [71,72].

\section{Recommendations}

1. Noninvasive assessments have a reduced risk and greater acceptance than liver biopsy, may enhance HCV screening and disease assessment among PWID, and should be offered, if available (B1).

2. Combining multiple noninvasive assessments is recommended, when possible (B1).

\section{Pretherapeutic Assessment}

Guidelines for pretherapeutic assessment for those with HCV are available $[37,38]$. However, HCV-infected PWID have complex social, medical, and psychiatric comorbidities, complicating decisions around care (reviewed in [73]). Poor HCV knowledge and inaccurate perceptions are barriers for accessing care [74-77]. Factors associated with not receiving HCV treatment include older age [78], minority ethnicity [78], ongoing or former drug use [79-81], ongoing alcohol use [78, 79], advanced liver disease [80], comorbid diseases $[78,81]$, psychiatric disease [78, 80], and OST [79].

\section{Recommendations}

1. Pretherapeutic education should include discussions of HCV transmission, risk factors for fibrosis progression, treatment, reinfection risk, and harm reduction strategies (B1).

2. Pretherapeutic assessment should include an evaluation of housing, education, cultural issues, social functioning and support, finances, nutrition, and drug and alcohol use. PWID should be linked to social support services and peer support, if available (A1).

\section{Indications for Treatment}

The goal of HCV therapy is to prevent liver disease complications and death from HCV. The end point is sustained virologic response (SVR), which equates to cure in $>99 \%$ of patients. SVR is associated with improved quality of life, regression of fibrosis, and reduced risk of complications in patients with cirrhosis [82].
According to international guidelines [37, 38], individuals with chronic HCV and absolute contraindications to standard of care should not receive therapy.

\section{Recommendations}

1. PWID should receive HCV assessment, with treatment decisions based on an individualized evaluation of social, lifestyle, and clinical factors (B1).

2. PWID with absolute contraindications to standard of care should not receive HCV therapy (B1).

\section{Peginterferon and DAA-Based Treatment}

In PWID, treatment of chronic HCV with pegylated interferon alfa (peg-IFN)/ribavirin (RBV) is safe and effective [4-35], and has been recommended for PWID by international guidelines following individualized assessment [37, 38]. DAA therapy, when added to peg-IFN/RBV, enhances treatment response for chronic HCV genotype 1 [83-86]. Future DAAs in combination with peg-IFN/RBV should provide improved efficacy, tolerability, dosing schedules, and therapy duration [87]. Evidence suggests that IFN-free DAA-based regimens are likely to be curative in a high proportion of individuals with chronic HCV genotype 2/3 [88, 89] and 1 [90-92] infections.

DAA clinical development programs have excluded individuals with active drug use, but many trials have included those on OST. DAA-based safety and treatment outcome data have not been presented on clinical trial subpopulations of individuals on OST. Drug-drug interaction studies have been undertaken on telaprevir and boceprevir with methadone $[93,94]$ and buprenorphine $[94,95]$, with no clinically important interactions observed.

\section{Recommendations}

1. Evaluation of safety and efficacy of telaprevir and boceprevir, in combination with peg-IFN/RBV, is required in PWID with chronic HCV genotype 1 (C1).

2. Telaprevir and boceprevir can be used in PWID on OST (B1).

3. Telaprevir and boceprevir do not require specific methadone and buprenorphine dose adjustment, but patients should be monitored for signs of opioid toxicity or withdrawal (B1).

4. Consideration of telaprevir and boceprevir use in PWID should be undertaken on an individualized basis, but those with early liver disease should generally be advised to await further data and/or potential development of improved DAAbased therapies (B1).

\section{Impact of Drug Use on Adherence and SVR}

Adherence to HCV therapy is often defined as receipt of $\geq 80 \%$ of scheduled peg-IFN/RBV for $\geq 80 \%$ of the treatment period, but this does not distinguish between missed doses and treatment discontinuation [96]. Suboptimal peg-IFN exposure is 
driven by early treatment discontinuation as compared to missed doses [97]. Both physicians [98] and individuals [99] overestimate adherence to HCV therapy. Adherence [96, 97] and treatment completion [96-98] are associated with SVR, but the impact of missed doses on SVR is unclear [96, 97]. Among PWID, adherence [29, 35, 97, 100] and treatment completion [97] are associated with SVR.

Peg-IFN/RBV is safe and effective among those with a history of IDU [4, 6-9, 11-35] and among active PWID [101], with SVR of $54 \%-56 \%[4,34,101]$. PWID often have characteristics associated with favorable $\mathrm{HCV}$ treatment response, including younger age, HCV genotype 3, and mild liver disease [9]. A history of IDU does not compromise adherence [97, 98, 102], treatment completion [4, 21, 29, 97], or SVR [4], although some studies have found lower treatment completion [4]. Recent drug use at treatment initiation has limited impact on adherence [29, 30, 97, 98, 100, 103], treatment completion [4, $28,29,97]$, or SVR [6, 7, 20, 24, 27-29, 35, 101]. Some studies have reported lower treatment completion in patients with recent drug use at treatment completion $[4,32]$. HCV treatment does not have an impact on drug dependency treatment or increase drug use $[17,18]$. Occasional drug use during treatment does not seem to impact adherence $[29,35,97,100]$, treatment completion [29, 97, 104], or SVR [7, 29, 35]. However, lower adherence $[97,98]$ and SVR $[19,20,24]$ have been observed in persons with frequent drug use (daily/every other day) during treatment. When discontinuation occurs, it often occurs early during therapy $[18,97]$. In adherent PWID, alcohol use does not impact SVR $[105,106]$.

Factors independently associated with adherence and treatment completion among PWID include lower education and unstable housing [97]. Factors independently associated with lower SVR among PWID include poor social functioning [7], a history of untreated depression [33], and ongoing drug use during treatment [33].

\section{Recommendations}

1. Adherence should consider missed doses and treatment discontinuation (B1).

2. PWID should be counseled on the importance of adherence in attaining SVR (A1).

3. HCV treatment can be considered for PWID, provided they wish to receive treatment and are able and willing to maintain regular appointments (A1).

4. A history of IDU and recent drug use at treatment initiation are not associated with reduced SVR, and decisions to treat must be made on a case-by-case basis (B1).

5. PWID with ongoing social issues or history of psychiatric disease and those with more frequent drug use during therapy are at risk of lower adherence and SVR and need to be monitored closely during therapy (B1).

\section{Impact of Mental Health on Adherence and SVR}

As reviewed in [107], psychiatric comorbidity is high among PWID. However, PWID do not have an increased risk for the development of major depression during peg-IFN treatment. Poorer social functioning is associated with new-onset depression during peg-IFN treatment [108]. Psychiatric comorbidity is not associated with lower adherence, treatment completion, SVR, or depression during peg-IFN treatment [26, 108-113].

As reviewed in [107], psychiatric contraindications to HCV therapy include acute major and uncontrolled psychiatric disorders. Although data are conflicting, studies show that prophylactic antidepressants can reduce IFN-induced depression, particularly in patients with previous or ongoing depression [107]. Depression-specific symptoms are responsive to serotonergic antidepressants [107]. Psychiatric adverse events related to peg-IFN can be managed without dose adjustment or discontinuation.

\section{Recommendations}

1. Pretreatment assessment should include an evaluation of previous or current psychiatric illness, engagement with a drug and alcohol counselor or psychiatrist, and discussions around potential treatment options (A1).

2. If psychiatric comorbidities are present, decisions to treat with peg-IFN must be made on a case-by-case basis (A1).

3. In cases of acute major and uncontrolled psychiatric disorders, a pretreatment psychiatric assessment is recommended (C2).

4. Prophylactic antidepressants are recommended in cases of a history of IFN-induced depression and with depressive symptoms at baseline (B1).

\section{Treatment Management}

HCV treatment has been delivered successfully to PWID through various models, including within hospital-based clinics, drug detoxification clinics, OST clinics, prisons, and community-based clinics. As reviewed in [114], strategies that have been successful for enhancing assessment, adherence, or SVR include hospital-based and primary care-based integrated care, community-based telehealth, nurse-led education, psychoeducation, directly observed therapy, peer support groups, and peer support workers. The key basis for effective HCV clinical management within these settings is access to a multidisciplinary team, generally including clinician and nursing clinical assessment and monitoring, drug and alcohol services, psychiatric services, and social work and other social support services (including peer support, if available).

\section{Recommendations}

1. HCV treatment for PWID should be considered on an individualized basis and delivered within a multidisciplinary team setting (B1). 
2. Access to harm reduction programs, social work, and social support services should be a component of HCV clinical management (B2).

3. Peer-based support should be evaluated as a means to improve HCV clinical management (B2).

\section{Reinfection Following Successful HCV Treatment}

There is still some concern that reinfection due to recurrent risk behaviors may negate potential benefits of treatment. Reported rates of reinfection following successful HCV treatment among PWID are low, with estimates generally $1 \%-5 \%$ risk per year (reviewed in [115]).

\section{Recommendations}

1. PWID should not be excluded from HCV treatment on the basis of perceived risk of reinfection (B1).

2. Harm reduction education and counseling should be provided for PWID in the context of HCV treatment (B1).

3. Following SVR, monitoring for $\mathrm{HCV}$ reinfection through annual HCV RNA assessment should be undertaken on PWID with ongoing risk behavior (B2).

\section{Treatment of Acute HCV}

Acute $\mathrm{HCV}$ infection refers to the period spanning the first 6 months following exposure to HCV [116]. Spontaneous clearance occurs in 25\% [53]. Peg-IFN-based SVR among HCVmonoinfected PWID with acute $\mathrm{HCV}$ is $55 \%-74 \%$ (reviewed in [116]), with treatment outcomes associated with adherence and social support, but not IDU prior to or during treatment [7].

\section{Recommendations}

1. PWID with acute HCV symptoms should be monitored for 12-16 weeks (including HCV RNA levels) to allow potential spontaneous clearance (A1).

2. Peg-IFN monotherapy for 24 weeks should be considered for PWID with acute HCV (B1).

3. Strategies to optimize adherence should be used in the setting of acute $\mathrm{HCV}$, with consideration of directly observed peg-IFN therapy (B2).

\section{HIV/HCV Coinfection}

Prevalence of $\mathrm{HCV}$ among HIV-infected PWID is high (>80\%) [117]. Chronic HCV is the leading cause of non-AIDS death where combination antiretroviral therapy (cART) is accessible [118]. Challenges with HIV/HCV include accelerated HCV disease progression, potential cART-related liver toxicity, multiple medication requirements, drug-drug interactions, and medical comorbidities (reviewed in [119]). HIV/HCV is associated with a higher prevalence of psychiatric disorders, poverty, homelessness, and incarceration [120]. HCV treatment responses may be poorer in those with HIV/HCV $[121,122]$.

\section{Recommendations}

1. HCV-infected PWID should be screened for HIV (B1).

2. The accelerated HCV disease progression in $\mathrm{HIV} / \mathrm{HCV}$ should be considered in treatment decision making (B2).

3. Potential drug-drug interactions between HIV, HCV, and OST need to be considered (A1).

4. Early introduction of cART should be considered (B1).

\section{Management of Hepatitis B Virus Coinfection}

The global prevalence of chronic hepatitis $\mathrm{B}$ virus (HBV) is $8 \%$ among PWID [44]. HBV vaccination is effective among PWID, and accelerated schedules improve adherence [123]. Peg-IFN/ $\mathrm{RBV}$ is effective for the treatment of $\mathrm{HCV}$ in persons with $\mathrm{HBV} / \mathrm{HCV}$ [124]. Hepatitis D virus coinfection is frequent in PWID [125]. Peg-IFN is the only effective drug [126].

\section{Recommendations}

1. PWID should be vaccinated for hepatitis A virus and $\mathrm{HBV}(\mathrm{A} 1)$.

2. PWID with active HBV/HCV coinfection should be considered for peg-IFN/RBV therapy (B1).

\section{Liver Transplantation}

The proportion of people with a history of IDU undergoing liver transplant for HCV-related cirrhosis or hepatocellular carcinoma is $5 \%-10 \%[127,128]$. Relapse to drug use following transplant is rare $[127,128]$. Selection criteria for liver transplantation include 6-24 months of drug abstinence, controlled psychiatric disease, and the presence of stable social support networks [129]. OST is not a contraindication [127, 129, 130]. There are no data in PWID.

\section{Recommendations}

1. Awareness should be raised that liver transplant is a therapeutic option in those with a history of IDU (B2).

2. OST is not a contraindication for liver transplantation, and individuals on OST should not be advised to reduce or stop therapy (A1).

3. Psychiatric evaluation and follow-up should be offered to PWID undergoing liver transplant (B1).

\section{CONCLUSIONS}

Given the burden of HCV-related disease among PWID, strategies to enhance $\mathrm{HCV}$ assessment and treatment in this group are urgently needed. These recommendations demonstrate that treatment among PWID is feasible and provides a framework for HCV assessment, management, and treatment. However, many studies performed among PWID to date are limited, given retrospective designs, small sample sizes, and lack of randomized controlled trial design. Further research is needed to 
evaluate strategies to enhance assessment, adherence, and SVR among PWID, particularly as new DAAs become available. This will be crucial in the efforts to stem the burden of HCVrelated liver disease worldwide.

\section{Notes}

Supplement sponsorship. This article was published as part of a supplement entitled "Prevention and Management of Hepatitis C Virus Among People Who Inject Drugs: Moving the Agenda Forward," sponsored by an unrestricted grant from the International Network on Hepatitis in Substance Users (INHSU), The Kirby Institute (University of New South Wales), Abbvie, Gilead Sciences, Janssen-Cilag, and Merck.

Potential conflicts of interest. All authors: No reported conflicts.

All authors have submitted the ICMJE Form for Disclosure of Potential Conflicts of Interest. Conflicts that the editors consider relevant to the content of the manuscript have been disclosed.

\section{References}

1. Shepard CW, Finelli L, Alter MJ. Global epidemiology of hepatitis C virus infection. Lancet Infect Dis 2005; 5:558-67.

2. Grebely J, Dore GJ. What is killing people with hepatitis C virus infection? Seminars Liver Dis 2011; 31:331-9.

3. National Institutes of Health. National Institutes of Health Consensus Development Conference Panel statement: management of hepatitis C. Hepatology 1997; 26(3 suppl 1):2S-10.

4. Hellard M, Sacks-Davis R, Gold J. Hepatitis C treatment for injection drug users: a review of the available evidence. Clin Infect Dis 2009; 49:561-73.

5. Grebely J, Knight E, Genoway KA, et al. Optimizing assessment and treatment for hepatitis $\mathrm{C}$ virus infection in illicit drug users: a novel model incorporating multidisciplinary care and peer support. Eur J Gastroenterol Hepatol 2010; 22:270-7.

6. Lindenburg CE, Lambers FA, Urbanus AT, et al. Hepatitis C testing and treatment among active drug users in Amsterdam: results from the DUTCH-C project. Eur J Gastroenterol Hepatol 2011; 23:23-31.

7. Dore GJ, Hellard M, Matthews GV, et al. Effective treatment of injecting drug users with recently acquired hepatitis $\mathrm{C}$ virus infection. Gastroenterology 2010; 138:123-35.e1-2.

8. Waizmann M, Ackermann G. High rates of sustained virological response in hepatitis $\mathrm{C}$ virus-infected injection drug users receiving directly observed therapy with peginterferon alpha-2a (40KD) (PEGASYS) and once-daily ribavirin. J Subst Abuse Treat 2010; 38:338-45.

9. Melin P, Chousterman M, Fontanges T, et al. Effectiveness of chronic hepatitis $\mathrm{C}$ treatment in drug users in routine clinical practice: results of a prospective cohort study. Eur J Gastroenterol Hepatol 2010; 22:1050-7.

10. Martinez AD, Dimova R, Marks KM, et al. Integrated internistaddiction medicine-hepatology model for hepatitis $\mathrm{C}$ management for individuals on methadone maintenance. J Viral Hepat 2010; 19: 47-54.

11. Van Thiel DH, Molloy PJ, Friedlander L, et al. Interferon alpha treatment of chronic hepatitis $\mathrm{C}$ in patients with evidence for co-existent autoimmune dysregulation. Hepatogastroenterology 1995; 42:900-6.

12. Backmund M, Meyer K, Von Zielonka M, Eichenlaub D. Treatment of hepatitis $C$ infection in injection drug users. Hepatology 2001; 34:188-93.

13. Dalgard O. Follow-up studies of treatment for hepatitis $\mathrm{C}$ virus infection among injection drug users. Clin Infect Dis 2005; 40(suppl 5): S336-8.

14. Sylvestre DL. Treating hepatitis $\mathrm{C}$ in methadone maintenance patients: an interim analysis. Drug Alcohol Depend 2002; 67:117-23.
15. Neri S, Bruno CM, Abate G, et al. Controlled clinical trial to assess the response of recent heroin abusers with chronic hepatitis $\mathrm{C}$ virus infection to treatment with interferon alpha-n2b. Clin Ther 2002; 24:1627-35.

16. Schaefer M, Schmidt F, Folwaczny C, et al. Adherence and mental side effects during hepatitis $\mathrm{C}$ treatment with interferon alfa and ribavirin in psychiatric risk groups. Hepatology 2003; 37:443-51.

17. Van Thiel DH, Anantharaju A, Creech S. Response to treatment of hepatitis $\mathrm{C}$ in individuals with a recent history of intravenous drug abuse. Am J Gastroenterol 2003; 98:2281-8.

18. Mauss S, Berger F, Goelz J, Jacob B, Schmutz G. A prospective controlled study of interferon-based therapy of chronic hepatitis $\mathrm{C}$ in patients on methadone maintenance. Hepatology 2004; 40:120-4.

19. Matthews G, Kronborg IJ, Dore GJ. Treatment for hepatitis C virus infection among current injection drug users in Australia. Clin Infect Dis 2005; 40(suppl 5):S325-9.

20. Sylvestre DL, Litwin AH, Clements BJ, Gourevitch MN. The impact of barriers to hepatitis $\mathrm{C}$ virus treatment in recovering heroin users maintained on methadone. J Subst Abuse Treat 2005; 29:159-65.

21. Robaeys G, Van Vlierberghe H, Mathei C, Van Ranst M, Bruckers L, Buntinx F. Similar compliance and effect of treatment in chronic hepatitis $\mathrm{C}$ resulting from intravenous drug use in comparison with other infection causes. Eur J Gastroenterol Hepatol 2006; 18:159-66.

22. Jeffrey GP, MacQuillan G, Chua F, et al. Hepatitis C virus eradication in intravenous drug users maintained with subcutaneous naltrexone implants. Hepatology 2007; 45:111-7.

23. Guadagnino V, Trotta MP, Montesano F, et al. Effectiveness of a multi-disciplinary standardized management model in the treatment of chronic hepatitis $\mathrm{C}$ in drug addicts engaged in detoxification programmes. Addiction 2007; 102:423-31.

24. Grebely J, Raffa JD, Meagher C, et al. Directly observed therapy for the treatment of hepatitis $\mathrm{C}$ virus infection in current and former injection drug users. J Gastroenterol Hepatol 2007; 22:1519-25.

25. Grebely J, Genoway K, Khara M, et al. Treatment uptake and outcomes among current and former injection drug users receiving directly observed therapy within a multidisciplinary group model for the treatment of hepatitis C virus infection. Int J Drug Policy 2007; 18:437-43.

26. Schaefer M, Hinzpeter A, Mohmand A, et al. Hepatitis C treatment in "difficult-to-treat" psychiatric patients with pegylated interferon-alpha and ribavirin: response and psychiatric side effects. Hepatology 2007; 46:991-8.

27. Bruggmann P, Falcato L, Dober S, et al. Active intravenous drug use during chronic hepatitis $\mathrm{C}$ therapy does not reduce sustained virological response rates in adherent patients. J Viral Hepat 2008; 15: 747-52.

28. Papadopoulos V, Gogou A, Mylopoulou T, Mimidis K. Should active injecting drug users receive treatment for chronic hepatitis C? Arq Gastroenterol 2010; 47:238-41.

29. Manolakopoulos S, Deutsch MJ, Anagnostou O, et al. Substitution treatment or active intravenous drug use should not be contraindications for antiviral treatment in drug users with chronic hepatitis C. Liver Int 2010; 30:1454-60.

30. Wilkinson M, Crawford V, Tippet A, et al. Community-based treatment for chronic hepatitis $\mathrm{C}$ in drug users: high rates of compliance with therapy despite ongoing drug use. Aliment Pharmacol Ther 2009; 29:29-37.

31. Jack K, Willott S, Manners J, Varnam MA, Thomson BJ. Clinical trial: a primary-care-based model for the delivery of anti-viral treatment to injecting drug users infected with hepatitis C. Aliment Pharmacol Ther 2009; 29:38-45.

32. Jafferbhoy H, Miller MH, Dunbar JK, Tait J, McLeod S, Dillon JF. Intravenous drug use: not a barrier to achieving a sustained virological response in HCV infection. J Viral Hepat 2012; 19:112-9.

33. Alvarez-Uria G, Day JN, Nasir AJ, Russell SK, Vilar FJ. Factors associated with treatment failure of patients with psychiatric diseases and 
injecting drug users in the treatment of genotype 2 or 3 hepatitis $C$ chronic infection. Liver Int 2009; 29:1051-5.

34. Dimova RB, Zeremski M, Jacobson IM, Hagan H, Des Jarlais DC, Talal AH. Determinants of hepatitis $\mathrm{C}$ virus treatment completion and efficacy in drug users assessed by meta-analysis. Clin Infect Dis 2012; 56:806-16.

35. Sasadeusz JJ, Dore G, Kronborg I, Barton D, Yoshihara M, Weltman M. Clinical experience with the treatment of hepatitis $\mathrm{C}$ infection in patients on opioid pharmacotherapy. Addiction 2011; 106: 977-84.

36. Sherman M, Bain V, Villeneuve JP, et al. The management of chronic viral hepatitis: a Canadian consensus conference 2004. Can J Gastroenterol 2004; 18:715-28.

37. Ghany MG, Strader DB, Thomas DL, Seeff LB. Diagnosis, management, and treatment of hepatitis C: an update. Hepatology 2009; 49:1335-74.

38. EASL clinical practice guidelines: management of hepatitis $C$ virus infection. J Hepatol 2011; 55:245-64.

39. Iversen J, Grebely J, Topp L, et al. Uptake of hepatitis C treatment among people who inject drugs attending Needle and Syringe Programs in Australia, 1999-2011 [published online ahead of print 1 July 2013]. J Viral Hepat 2013; doi:10.1111/jvh.12129.

40. Mehta SH, Genberg BL, Astemborski J, et al. Limited uptake of hepatitis $\mathrm{C}$ treatment among injection drug users. J Community Health 2008; 33:126-33.

41. Grebely J, Raffa JD, Lai C, et al. Low uptake of treatment for hepatitis $\mathrm{C}$ virus infection in a large community-based study of inner city residents. J Viral Hepat 2009; 16:352-8.

42. Strathdee SA, Latka M, Campbell J, et al. Factors associated with interest in initiating treatment for hepatitis C Virus (HCV) infection among young HCV-infected injection drug users. Clin Infect Dis 2005; 40(suppl 5):S304-12.

43. Hutchinson SJ, Bird SM, Goldberg DJ. Modeling the current and future disease burden of hepatitis $\mathrm{C}$ among injection drug users in Scotland. Hepatology 2005; 42:711-23.

44. Nelson PK, Mathers BM, Cowie B, et al. Global epidemiology of hepatitis $B$ and hepatitis $C$ in people who inject drugs: results of systematic reviews. Lancet 2011; 378:571-83.

45. Hagan H, Pouget ER, Des Jarlais DC, Lelutiu-Weinberger C. Meta-regression of hepatitis $\mathrm{C}$ virus infection in relation to time since onset of illicit drug injection: the influence of time and place. Am J Epidemiol 2008; 168:1099-109.

46. Pybus OG, Cochrane A, Holmes EC, Simmonds P. The hepatitis C virus epidemic among injecting drug users. Infect Genet Evol 2005; 5:131-9.

47. van Asten L, Verhaest I, Lamzira S, et al. Spread of hepatitis C virus among European injection drug users infected with HIV: a phylogenetic analysis. J Infect Dis 2004; 189:292-302.

48. Sievert W, Altraif I, Razavi HA, et al. A systematic review of hepatitis C virus epidemiology in Asia, Australia and Egypt. Liver Int 2011; 31(suppl 2):61-80.

49. Turner KM, Hutchinson S, Vickerman P, et al. The impact of needle and syringe provision and opiate substitution therapy on the incidence of hepatitis $\mathrm{C}$ virus in injecting drug users: pooling of UK evidence. Addiction 2011; 106:1978-88.

50. Hagan H, Pouget ER, Des Jarlais DC. A systematic review and metaanalysis of interventions to prevent hepatitis $\mathrm{C}$ virus infection in people who inject drugs. J Infect Dis 2011; 204:74-83.

51. van den Berg CH, Smit C, Bakker M, et al. Major decline of hepatitis $\mathrm{C}$ virus incidence rate over two decades in a cohort of drug users. Eur J Epidemiol 2007; 22:183-93.

52. Martin NK, Vickerman P, Foster GR, Hutchinson SJ, Goldberg DJ, Hickman M. Can antiviral therapy for hepatitis $C$ reduce the prevalence of $\mathrm{HCV}$ among injecting drug user populations? A modeling analysis of its prevention utility. J Hepatol 2011; 54:1137-44.
53. Micallef JM, Kaldor JM, Dore GJ. Spontaneous viral clearance following acute hepatitis $\mathrm{C}$ infection: a systematic review of longitudinal studies. J Viral Hepat 2006; 13:34-41.

54. John-Baptiste A, Krahn M, Heathcote J, Laporte A, Tomlinson G. The natural history of hepatitis $\mathrm{C}$ infection acquired through injection drug use: meta-analysis and meta-regression. J Hepatol 2010; 53: 245-51.

55. Rehm J, Frick U, Hartwig C, Gutzwiller F, Gschwend P, Uchtenhagen A. Mortality in heroin-assisted treatment in Switzerland 1994-2000. Drug Alcohol Depend 2005; 79:137-43.

56. Kreek MJ, Dodes L, Kane S, Knobler J, Martin R. Long-term methadone maintenance therapy: effects on liver function. Ann Intern Med 1972; 77:598-602.

57. Petry NM, Bickel WK, Piasecki D, Marsch LA, Badger GJ. Elevated liver enzyme levels in opioid-dependent patients with hepatitis treated with buprenorphine. Am J Addict 2000; 9:265-9.

58. Andreu V, Mas A, Bruguera M, et al. Ecstasy: a common cause of severe acute hepatotoxicity. J Hepatol 1998; 29:394-7.

59. Turillazzi E, Riezzo I, Neri M, Bello S, Fineschi V. MDMA toxicity and pathological consequences: a review about experimental data and autopsy findings. Curr Pharm Biotechnol 2010; 11:500-9.

60. Karch SB, Stephens BG, Ho CH. Methamphetamine-related deaths in San Francisco: demographic, pathologic, and toxicologic profiles. J Forensic Sci 1999; 44:359-68.

61. Hutchinson SJ, Bird SM, Goldberg DJ. Influence of alcohol on the progression of hepatitis $\mathrm{C}$ virus infection: a meta-analysis. Clin Gastroenterol Hepatol 2005; 3:1150-9.

62. Mallat A, Hezode C, Lotersztajn S. Environmental factors as disease accelerators during chronic hepatitis C. J Hepatol 2008; 48: 657-65.

63. Hezode C, Roudot-Thoraval F, Nguyen S, et al. Daily cannabis smoking as a risk factor for progression of fibrosis in chronic hepatitis C. Hepatology 2005; 42:63-71.

64. Ishida JH, Peters MG, Jin C, et al. Influence of cannabis use on severity of hepatitis C disease. Clin Gastroenterol Hepatol 2008; 6:69-75.

65. Costentin CE, Roudot-Thoraval F, Zafrani ES, et al. Association of caffeine intake and histological features of chronic hepatitis C. J Hepatol 2011; 54:1123-9.

66. Modi AA, Feld JJ, Park Y, et al. Increased caffeine consumption is associated with reduced hepatic fibrosis. Hepatology 2010; 51:201-9.

67. Shaheen AA, Wan AF, Myers RP. FibroTest and FibroScan for the prediction of hepatitis C-related fibrosis: a systematic review of diagnostic test accuracy. Am J Gastroenterol 2007; 102:2589-600.

68. Vergniol J, Foucher J, Terrebonne E, et al. Noninvasive tests for fibrosis and liver stiffness predict 5 -year outcomes of patients with chronic hepatitis C. Gastroenterology 2011; 140:1970-9, 9.e1-3.

69. Baranova A, Lal P, Birerdinc A, Younossi ZM. Non-invasive markers for hepatic fibrosis. BMC Gastroenterol 2011; 11:91.

70. Liu S, Schwarzinger M, Carrat F, Goldhaber-Fiebert JD. Cost effectiveness of fibrosis assessment prior to treatment for chronic hepatitis $\mathrm{C}$ patients. PLoS One 2011; 6:e26783.

71. Moessner BK, Jorgensen TR, Skamling M, et al. Outreach screening of drug users for cirrhosis with transient elastography. Addiction 2011; 106:970-6.

72. Foucher J, Reiller B, Jullien V, et al. FibroScan used in street-based outreach for drug users is useful for hepatitis $C$ virus screening and management: a prospective study. J Viral Hepat 2009; 16:121-31.

73. Grebely J, Tyndall MW. Management of HCV and HIV infections among people who inject drugs. Curr Opin HIV AIDS 2011; 6:501-7.

74. Grebely J, Genoway KA, Raffa JD, et al. Barriers associated with the treatment of hepatitis $\mathrm{C}$ virus infection among illicit drug users. Drug Alcohol Depend 2008; 93:141-7.

75. Treloar C, Hull P, Bryant J, Hopwood M, Grebely J, Lavis Y. Factors associated with hepatitis $\mathrm{C}$ knowledge among a sample of treatment naive people who inject drugs. Drug Alcohol Depend 2011; 116:52-6. 
76. Treloar C, Newland J, Rance J, Hopwood M. Uptake and delivery of hepatitis $\mathrm{C}$ treatment in opiate substitution treatment: perceptions of clients and health professionals. J Viral Hepat 2010; 17:839-44.

77. Doab A, Treloar C, Dore GJ. Knowledge and attitudes about treatment for hepatitis $\mathrm{C}$ virus infection and barriers to treatment among current injection drug users in Australia. Clin Infect Dis 2005; 40 (suppl 5):S313-20.

78. Kramer JR, Kanwal F, Richardson P, Giordano TP, Petersen LA, ElSerag HB. Importance of patient, provider, and facility predictors of hepatitis $C$ virus treatment in veterans: a national study. Am J Gastroenterol 2011; 106:483-91.

79. Gidding HF, Law MG, Amin J, et al. Predictors of deferral of treatment for hepatitis C infection in Australian clinics. Med J Aust 2011; 194:398-402.

80. Bini EJ, Brau N, Currie S, et al. Prospective multicenter study of eligibility for antiviral therapy among 4,084 U.S. veterans with chronic hepatitis C virus infection. Am J Gastroenterol 2005; 100:1772-9.

81. Kanwal F, Hoang T, Spiegel BM, et al. Predictors of treatment in patients with chronic hepatitis $\mathrm{C}$ infection-role of patient versus nonpatient factors. Hepatology 2007; 46:1741-9.

82. Seeff LB. Natural history of chronic hepatitis C. Hepatology 2002; 36 (5 suppl 1):S35-46.

83. Jacobson IM, McHutchison JG, Dusheiko G, et al. Telaprevir for previously untreated chronic hepatitis $\mathrm{C}$ virus infection. $\mathrm{N}$ Engl J Med 2011; 364:2405-16.

84. Zeuzem S, Andreone P, Pol S, et al. Telaprevir for retreatment of HCV infection. N Engl J Med 2011; 364:2417-28.

85. Poordad F, McCone J Jr., Bacon BR, et al. Boceprevir for untreated chronic HCV genotype 1 infection. $N$ Engl J Med 2011; 364: 1195-206.

86. Bacon BR, Gordon SC, Lawitz E, et al. Boceprevir for previously treated chronic HCV genotype 1 infection. N Engl J Med 2011; 364: 1207-17.

87. Hofmann WP, Zeuzem S. A new standard of care for the treatment of chronic HCV infection. Nat Rev Gastroenterol Hepatol 2011; 8: $257-64$.

88. Jacobson IM, Gordon SC, Kowdley KV, et al. Sofosbuvir for hepatitis C genotype 2 or 3 in patients without treatment options. N Engl J Med 2013; 368:1867-77.

89. Lawitz E, Mangia A, Wyles D, et al. Sofosbuvir for previously untreated chronic hepatitis C infection. N Engl J Med 2013; 368:1878-87.

90. Chayama K, Takahashi S, Kawakami Y, et al. Dual oral combination therapy with the NS5A inhibitor BMS-790052 and the NS3 protease inhibitor BMS-650032 achieved 90\% sustained virological response (SVR12) in HCV genotype 1b-infected null responders. Hepatology 2011; 54(4 suppl):1428A.

91. Lok AS, Gardiner DF, Lawitz E, et al. Preliminary study of two antiviral agents for hepatitis C genotype 1. N Engl J Med 2012; 366:216-24.

92. Poordad F, Lawitz E, Kowdley KV, et al. 12-week interferon-free regimen of ABT-450/r+ABT-333+ribavirin achieved SVR12 in more than $90 \%$ of treatment-naive HCV genotype-1-infected subjects and 47\% of previous non-responders. J Hepatol 2012; 56:S549-50.

93. van Heeswijk R, Vandevoorde A, Verboven P, et al. Pharmacokinetic interaction between telaprevir and methadone. Antimicrob Agents Chemother 2013; 57:2304-9.

94. Hulskotte EGJ, Feng H, Bruce DR, et al. Pharmacokinetic interaction between $\mathrm{HCV}$ protease inhibitor boceprevir and methadone or buprenorphine in subjects on stable maintenance therapy. Abstract PK 09. In: Seventh International Workshop on Clinical Pharmacology of Hepatitis Therapy, Cambridge, MA, 27-28 June 2012.

95. Luo X, Trevejo J, Van Heeswijk RP, Smith F, Garg V. Effect of telaprevir on the pharmacokinetics of buprenorphine in volunteers on stable buprenorphine/naloxone maintenance therapy. Antimicrob Agents Chemother 2012; 56:3641-7.

96. Weiss JJ, Brau N, Stivala A, Swan T, Fishbein D. Review article: adherence to medication for chronic hepatitis C-building on the model of human immunodeficiency virus antiretroviral adherence research. Aliment Pharmacol Ther 2009; 30:14-27.

97. Grebely J, Matthews GV, Hellard M, et al. Adherence to treatment for recently acquired hepatitis $\mathrm{C}$ virus (HCV) infection among injecting drug users. J Hepatol 2011; 55:76-85.

98. Marcellin P, Chousterman M, Fontanges T, et al. Adherence to treatment and quality of life during hepatitis $\mathrm{C}$ therapy: a prospective, reallife, observational study. Liver Int 2011; 31:516-24.

99. Smith SR, Wahed AS, Kelley SS, Conjeevaram HS, Robuck PR, Fried MW. Assessing the validity of self-reported medication adherence in hepatitis C treatment. Ann Pharmacother 2007; 41:1116-23.

100. Sylvestre DL, Clements BJ. Adherence to hepatitis C treatment in recovering heroin users maintained on methadone. Eur J Gastroenterol Hepatol 2007; 19:741-7.

101. Aspinall E, Corson S, Doyle J, et al. Peginterferon and ribavirin treatment for chronic hepatitis $\mathrm{C}$ virus in people who inject drugs: a systematic review and meta-analysis. Clin Infect Dis 2013; 57(Suppl 2):S80-9.

102. Lo Re V 3rd, Amorosa VK, Localio AR, et al. Adherence to hepatitis C virus therapy and early virologic outcomes. Clin Infect Dis 2009; 48:186-93.

103. Sola R, Galeras JA, Montoliu S, et al. Poor response to hepatitis C virus (HCV) therapy in HIV- and HCV-coinfected patients is not due to lower adherence to treatment. AIDS Res Hum Retroviruses 2006; 22:393-400.

104. Cournot M, Glibert A, Castel F, et al. Management of hepatitis C in active drugs users: experience of an addiction care hepatology unit. Gastroenterol Clin Biol 2004; 28(6-7 Pt 1):533-9.

105. Anand BS, Currie S, Dieperink E, et al. Alcohol use and treatment of hepatitis $C$ virus: results of a national multicenter study. Gastroenterology 2006; 130:1607-16.

106. Bruggmann P, Dampz M, Gerlach T, Kravecz L, Falcato L. Treatment outcome in relation to alcohol consumption during hepatitis C therapy: an analysis of the Swiss Hepatitis C Cohort Study. Drug Alcohol Depend 2010; 110:167-71.

107. Schaefer M, Sarkar R, Diez-Quevedo C. Management of mental health problems prior to and during treatment of $\mathrm{HCV}$ infection in patients with drug addiction. Clin Infect Dis 2013; 57(Suppl 2):S111-7.

108. Alavi M, Grebely J, Matthews GV, et al. Impact of pegylated interferon alfa-2a treatment on mental health during recent hepatitis $C$ virus infection. J Gastroenterol Hepatol 2012; 27:957-65.

109. Hauser $\mathrm{P}$, Khosla J, Aurora $\mathrm{H}$, et al. A prospective study of the incidence and open-label treatment of interferon-induced major depressive disorder in patients with hepatitis C. Mol Psychiatry 2002; 7:942-7.

110. Kraus MR, Schafer A, Faller H, Csef H, Scheurlen M. Psychiatric symptoms in patients with chronic hepatitis $\mathrm{C}$ receiving interferon alfa-2b therapy. J Clin Psychiatry 2003; 64:708-14.

111. Evon DM, Ramcharran D, Belle SH, et al. Prospective analysis of depression during peginterferon and ribavirin therapy of chronic hepatitis $\mathrm{C}$ : results of the Virahep-C study. Am J Gastroenterol 2009; 104:2949-58.

112. Schmidt F, Janssen G, Martin G, et al. Factors influencing long-term changes in mental health after interferon-alpha treatment of chronic hepatitis C. Aliment Pharmacol Ther 2009; 30:1049-59.

113. Hauser P, Morasco BJ, Linke A, et al. Antiviral completion rates and sustained viral response in hepatitis $C$ patients with and without preexisting major depressive disorder. Psychosomatics 2009; 50:500-5.

114. Bruggmann P, Litwin AH. Models of care for the management of HCV among people who use drugs: one size does not fit all. Clin Infect Dis 2013; 57(Suppl 2):S56-61.

115. Grady B, Schinkel J, Dalgard O. Hepatitis C virus reinfection following treatment among people who use drugs. Clin Infect Dis 2013; 57 (Suppl 2):S105-10.

116. Grebely J, Matthews GV, Dore GJ. Treatment of acute HCV infection. Nat Rev Gastroenterol Hepatol 2011; 8:265-74.

117. Strader DB. Coinfection with HIV and hepatitis C virus in injection drug users and minority populations. Clin Infect Dis 2005; 41(suppl 1): S7-13. 
118. Weber R, Sabin CA, Friis-Moller N, et al. Liver-related deaths in persons infected with the human immunodeficiency virus: the D:A:D study. Arch Intern Med 2006; 166:1632-41.

119. Taylor LE, Swan T, Matthews GV. Management of HCV/HIV coinfection among people who use drugs in the era of direct-acting antiviralbased therapy. Clin Infect Dis 2013; 57(Suppl 2):S118-24.

120. Rosenberg SD, Drake RE, Brunette MF, Wolford GL, Marsh BJ. Hepatitis $\mathrm{C}$ virus and HIV co-infection in people with severe mental illness and substance use disorders. AIDS 2005; 19(suppl 3):S26-33.

121. Torriani FJ, Rodriguez-Torres M, Rockstroh JK, et al. Peginterferon alfa-2a plus ribavirin for chronic hepatitis $\mathrm{C}$ virus infection in HIV-infected patients. N Engl J Med 2004; 351:438-50.

122. Chung RT, Andersen J, Volberding P, et al. Peginterferon alfa-2a plus ribavirin versus interferon alfa-2a plus ribavirin for chronic hepatitis C in HIV-coinfected persons. N Engl J Med 2004; 351:451-9.

123. Hwang LY, Grimes CZ, Tran TQ, et al. Accelerated hepatitis B vaccination schedule among drug users: a randomized controlled trial. J Infect Dis 2010; 202:1500-9.
124. Liu CJ, Chuang WL, Lee CM, et al. Peginterferon alfa-2a plus ribavirin for the treatment of dual chronic infection with hepatitis $\mathrm{B}$ and $\mathrm{C}$ viruses. Gastroenterology 2009; 136:496-504.e3.

125. Kucirka LM, Farzadegan H, Feld JJ, et al. Prevalence, correlates, and viral dynamics of hepatitis delta among injection drug users. J Infect Dis 2010; 202:845-52.

126. Rizzetto M. Current management of delta hepatitis. Liver Int 2013; 33 (suppl 1):195-7.

127. De Gottardi A, Hilleret MN, Gelez P, et al. Injection drug use before and after liver transplantation: a retrospective multicenter analysis on incidence and outcome. Clin Transplant 2010; 24:564-71.

128. Robaeys G, Nevens F, Starkel P, et al. Previous intravenous substance use and outcome of liver transplantation in patients with chronic hepatitis C infection. Transplant Proc 2009; 41:589-94.

129. Webb K, Shepherd L, Neuberger J. Illicit drug use and liver transplantation: is there a problem and what is the solution? Transpl Int 2008; 21:923-9.

130. Kanchana TP, Kaul V, Manzarbeitia C, et al. Liver transplantation for patients on methadone maintenance. Liver Transpl 2002; 8:778-82. 